\title{
The Carbon Ask: effects of climate policy on the value of fossil fuel resources and the implications for technological innovation
}

\author{
Peter Linquiti $^{1} \cdot$ Nathan Cogswell $^{1}$
}

Published online: 12 May 2016

(C) The Author(s) 2016. This article is published with open access at Springerlink.com

\begin{abstract}
Strong policies to address climate change will almost certainly require that large quantities of oil, natural gas, and coal remain underground. Because these resources have economic value, action to reduce carbon emissions means that fossil fuel owners and producers, and other entities in the fossil fuel supply chain, will experience a reduction in wealth. They will be on the receiving end of what we call the "Carbon Ask." We compile disparate data sources, make some simplifying assumptions, and approximate the value of the Carbon Ask for the world as a whole. We find that the value of the world's fossil fuel enterprise in a business-as-usual case, unconstrained by climate policy, is about $\$ 295$ trillion. In a world with a strong climate policy, the value of these resources drops to about $\$ 110$ trillion, a decrease of $\$ 185$ trillion, or $63 \%$. The Carbon Ask is equivalent to 2.4 years of global GDP. After reviewing the literature on resistance to technological innovation during the past two centuries and examining legal challenges to recent US greenhouse gas regulations, we find it unsurprising that the Carbon Ask creates powerful incentives for many stakeholders - who may be firms, workers, consumers, and governments - to resist policies to speed the development and diffusion of new, more environmentally benign technologies. We also find few precedents for policy-driven, rather than market-driven, technological transformations with a scale and scope similar to decarbonization of the global economy.
\end{abstract}

Electronic supplementary material The online version of this article (doi:10.1007/s13412-016-0397-2) contains supplementary material, which is available to authorized users.

Peter Linquiti linquiti@gwu.edu

1 Environmental Resource Policy Program, George Washington University, Washington, DC, USA
Keywords Carbon Ask · Stranded asset · Decarbonization · Carbon budget $\cdot$ Emissions budget $\cdot$ Fossil fuel reserves . Fossil fuel resources

\section{Introduction $^{1}$}

Domestic politics in the United States notwithstanding, there is generally a global consensus that climate change is an urgent concern requiring international action. In 2015, 195 countries adopted the Paris Agreement, a commitment to a process for making emission reductions to hold the increase in global temperature to "well below" $2{ }^{\circ} \mathrm{C}$ above pre-industrial levels and to "pursue efforts" to hold the increase to $1.5^{\circ} \mathrm{C}$ (COP21 2015, p. 22). Fulfilling the Paris Agreement will likely require that large quantities of oil, natural gas, and coal remain in the ground. Because these resources have economic value, leaving them underground is like taking a write-off on the world's capital asset balance sheet. A strong climate policy will also likely depress demand for, and the price of, fossil fuels that are produced. In short, action to reduce emissions means that fossil fuel owners, and other entities in the fossil fuel supply chain, will be askedin a political sense - to accept a reduction in wealth. They will be on the receiving end of what we call the "Carbon Ask."

Underground fossil fuels are not just a source of value for multinational firms and of revenue for wealthy governments. Many actors have a stake in carbon assets: middle-class citizens with retirement holdings in oil, gas, and coal securities; developing countries with ample fossil fuel resources but low standards of living; and impoverished Appalachian towns

\footnotetext{
${ }^{1}$ Additional information on global fossil fuel quantities is contained in a Technical Appendix. We would like to thank Irene Kim for her work as a research assistant. In addition, valuable comments were provided by Gerald Brock, Nancy Augustine, and two anonymous reviewers.
} 
where coal mining is the only driver of economic activity. Add in the supply chain - manufacturers of drilling and mining equipment; field service companies that support oil and gas exploration and production; railroads, pipelines, and tanker fleets that bring fossil fuels to market; and workers in all these sectors - and the list of stakeholders gets longer. These participants in the global fossil fuel enterpise are also on the receiving end of the Carbon Ask.

In this paper, we put a price tag on the Carbon Ask. We compile disparate data, make simplifying assumptions, and approximate its global value. Although our result can be fairly called a back-of-the-envelope estimate, we find the Carbon Ask to be so large that it is clearly relevant to climate policymaking. In addition, after reviewing the literature on technological innovation and examining legal challenges to recent US greenhouse gas (GHG) regulations, we are convinced that the size of the Carbon Ask helps to explain the behavior of those who aim to impede action on climate change.

We do not question the threats posed by climate change nor the need for prompt and effective policy (IPCC 2014). And while it is tempting to try to tell a broader story by juxtaposing the Carbon Ask against an estimate of the cost of global warming, doing so is no easy task. Although $89 \%$ of expert climate economists believe that climate change is already negatively affecting the global economy or will do so by 2050 (Howard and Sylvan 2015), the academic literature reflects a lively debate about the size of these effects. Some economists believe that the social cost of GHG emissions is about $\$ 20$ per ton of $\mathrm{CO}_{2}$, while others suggest that it could be as high as $\$ 200$ per ton (Pindyck 2013). Rather than engaging this debate, we choose to focus more narrowly on one element of the issue. We also recognize that by estimating the lost economic value of fossil fuel resources, we may lend credence to arguments made by advocates whose sole objective is to obstruct climate policy. For us, however, the value of an informed debate trumps the risk of our findings being taken out of context.

We start by exploring the technological transformation needed to address climate change and then put that transformation into context by reviewing similar transformations over the past 200 years. Next, we review key concepts in the idea of the Carbon Ask and specify the attributes of a sound approach to estimating its magnitude. We then describe the methodology, data, and results of our quantitative analysis. We conclude by discussing the practical implications of our findings.

\section{Climate policy as technology transformation}

Translating a specific temperature increase goal into actionable policy depends in part on the link between emissions and temperature change. Because $\mathrm{CO}_{2}$ persists in the atmosphere for decades, its impact on the climate is not especially sensitive to when it is released. Accordingly, analysts often talk about a budget that can be spent (in the form of ongoing $\mathrm{CO}_{2}$ emissions) over time. ${ }^{2}$ The IPCC reported that if post2011 emissions stay within a budget of 1300 gigatons (Gt), there is a $50 \%$ probability of holding warming to under $2{ }^{\circ} \mathrm{C}$ (2014, p. 64). Satisfying this emission budget, while accommodating global population and economic growth, will require a radical transformation in how the world produces and uses energy. Recognizing this challenge, the G-7 Heads of State called for "decarbonization" of the global economy by 2100 (G-7 2015, p. 12). Along the way, profound technological, economic, social, and institutional obstacles must be overcome (IPCC 2014). Or, in plain language, “you're fooling yourself if you think getting off fossil fuels will be simple. It will be one of the most difficult challenges modern civilization has ever faced" (Wagner and Weitzman 2015, p. ix).

Radical technological transformations, akin to decarbonization of the world's economy, are not unprecedented. The Industrial Revolution, the shift from horses and sailing ships to mechanized transport, and the rapid pace of innovation in information technology are examples of what Joseph Schumpeter called "creative destruction" (Schumpeter 1943, p. 83). For Schumpeter, two phenomena - creation and destruction-must occur if significant technological changes are to diffuse throughout an economy. First, inventors and entrepreneurs must "create" new technologies that are, in some way, superior to existing technologies. Second, users must abandon existing technologies (the "destruction" phase) and adopt the new technology. Scholars continue work to understand the political economy of technological progress (Balalaeva 2015; Acemoglu et al. 2014; Sapolsky and Taylor 2011; Comin and Hobijn 2009; Chaudhry and Garner 2007; Acemoglu and Robinson 2000; Rogers 1995; Mokyr 1992; Reinganum 1989; David 1985; Kamien and Schwartz 1982; Rosenberg 1972; Mansfield 1961).

From the narrow microeconomic view of a firm or consumer, the process of technology adoption is a matter of benefits, costs, and uncertainty (Linquiti 2015; Hall 2005; Tassey 1997). First, the benefits of the new technology are weighed against those of the current technology. Benefits may stem from lower operating costs, better quality outputs, or new features valued by users. Offsetting the benefits of a new technology are its costs, which may include acquisition and operating costs, as well as the cost of transitioning from an existing technology to a new one. Beyond costs and benefits, potential technology adopters consider uncertainties about costs, reliability, and performance, as well as about customer and competitor responses to the new technology. In this framework,

\footnotetext{
${ }^{2}$ Meinshausen et al. appear to be among the first to use the term "budget" (2009, p. 1158), while others refer to the same concept as an emissions "quota" (Raupach et al. 2014, p. 873).
} 
new technologies are adopted when benefits exceed costs to a degree sufficient to offset residual uncertainties.

When it comes to technological transformations with large economic consequences, however, the standard microeconomic framework is incomplete because it ignores the tendency of powerful economic interests to exert political pressure on the policymaking process to protect incumbent technology providers and impede technological newcomers (Acemoglu et al. 2014; Hirth and Uekerdt 2013; Sapolsky and Taylor 2011). Shifting the focus from microeconomics to the broader field of political economy, we find ample evidence of the ability of vested interests to affect the trajectory of technological progress. For example, having studied resistance to new technologies in Britain and France during the Industrial Revolution, Mokyr concludes that

Writing economic history as if there were no political history is unacceptable. ... Resistance to progress, when it came from a well-organized lobby of potential losers, served the narrow interests of a small and selfish group at the expense of the social good. ... In the historical experience the irrelevancy of such [neoclassical economic] models is apparent; the friction caused by technological shocks is an inescapable part of the story because technological change not only expanded the supply of resources, it involved their transfer from the status quo to newcomers (1992, pp. 326, 328-329).

More recently, Comin and Hobijn reviewed the diffusion of 20 transformative technologies over 215 years in 23 of the world's major economies in fields like steel-making, communication, and transportation (2009). In cases where a new technology had a competing predecessor technology (implying a vested interest threatened by the innovation), the power of lobbies was used to "significantly slow the speed of diffusion of new technologies" (p. 242). The effect was not observed when there was no competing predecessor technology. Balalaeva examined patent data from 100 countries over 20 years and found that countries with governance structures that allow technology innovators open access to political power, in turn, experience higher levels of technological progress. Conversely, if technology incumbents can block access to political power by newcomers, then national rates of innovation suffer appreciably (Balalaeva 2015).

\section{Prior analyses relevant to measuring the Carbon Ask}

McKibben drew popular attention to underground carbon in a Rolling Stone article that linked a $2{ }^{\circ} \mathrm{C}$ temperature target first to a carbon budget and then to an estimate of subsurface fossil fuels and concluded that $80 \%$ of fossil fuel reserves should remain underground (2012). In the same vein, but taking a more rigorous approach, McGlade and Ekins assessed the quantity, location, and production cost of global fossil fuel resources (2015). They then applied a cost minimization algorithm to determine that "globally, a third of oil reserves, half of gas reserves and over 80 percent of current coal reserves should remain unused from 2010 to 2050 in order to meet the target of $2^{\circ} \mathrm{C} "$ (p. 187).

The Capital Institute identified a "stranded asset risk" that might lead firms and governments to abandon $\$ 20$ trillion in fossil fuel reserves (Fullerton 2011). That analysis suggests that the world's 100 largest publicly listed coal mining companies and the 100 largest publicly listed oil and gas extraction companies have a market capitalization of $\$ 7$ trillion. Fullerton claims that these firms own $26 \%$ of the world's fossil fuel reserves. Assuming that markets would value government- and privately-held reserves as they do reserves owned by publicly listed firms, and that such firms are valued solely as a function of proved reserves, he scales the firm valuations to a value of $\$ 27$ trillion for global reserves. Finally, he applies a carbon budget constraint that no more than $20 \%$ of fossil fuel reserves can be burned, yielding an estimated $\$ 20$ trillion in stranded assets.

A 2013 Carbon Tracker Initiative (CTI) report suggested that 60 to $80 \%$ of publicly traded firms' oil, gas, and coal reserves cannot be used under a $2{ }^{\circ} \mathrm{C}$ scenario (Leaton et al. 2013). In 2012, these firms spent $\$ 674$ billion to find and develop new reserves, an investment characterized as "wasted capital." In a more recent analysis, CTI estimated the reduction in capital spending for oil, gas, and coal exploration and development (from 2015 to 2025) that would result from policies to hold warming to $2{ }^{\circ} \mathrm{C}$-in contrast to a business-asusual case - at $\$ 2$ trillion (Fulton et al. 2015). In both analyses, CTI calls on investors and regulators to ensure that markets better account for climate policies in firm valuations and capital allocations. CTI argues that rather than investing in exploration and development, fossil fuel firms should return funds to shareholders through dividends and share buybacks. On the other hand, Heede and Oreskes conclude that the vast majority of proved reserves are not owned by private actors but by governments around the world (2016). Neither Heede and Oreskes nor CTI monetize the value of subsurface resources.

Bauer et al. estimated the present value of the change in fossil fuel rents from 2010 to 2100 that would result from a policy to hold $\mathrm{CO}_{2}$ concentrations to $450 \mathrm{ppm}$, roughly corresponding to warming of $2{ }^{\circ} \mathrm{C}$ (2013). Rents, also called profits by the authors, are defined as the difference between price and production plus transportation cost. The authors report that climate policy would decrease the present value of fossil fuel rents from $\$ 29.9$ trillion to $\$ 17.5$ trillion, a difference of $\$ 12.4$ trillion. 
Investment banking firm Kepler Cheuvreux investigated the effect of climate policy on revenues of oil, gas, and coal producers (Lewis 2014). Its report relies on work done by the International Energy Agency (IEA) which projected the production and pricing of fossil fuels under alternative policy scenarios between 2013 and 2035. Lewis compares a base case where some modest climate initiatives occur to a policy case where aggressive action is taken to hold warming to within $2{ }^{\circ} \mathrm{C}$. Annual revenues are computed, as price times quantity, over the 23-year analysis period for both the base and policy cases, and then summed without being discounted. Results suggest that climate policy would reduce revenues by $\$ 28.3$ trillion.

In 2014, the Climate Policy Initiative (CPI) reported on the lost asset values associated with policies to limit warming to $2{ }^{\circ} \mathrm{C}$ (Nelson et al. 2014). Like Lewis, CPI used two IEA scenarios to characterize the policy environment for fossil fuels, but while the policy case is the same, the base case differs. CPI used an IEA businessas-usual scenario that includes no policy changes as its base case, while Lewis used as his base case an IEA scenario that assumes implementation of some climate policies currently under development. While it relied on IEA's scenarios to predict fossil fuel demand, CPI used its own supply cost models for oil, natural gas, coal, and electric power markets around the world to predict the supply response to the IEA demand estimates. The analysis is done for each year between 2015 and 2035, and lost profits are discounted at $8 \%$. The result is a decrease in profits of $\$ 24.6$ trillion, which the authors characterize as "value at risk."

Finally, a Citigroup report estimates that global climate policy would result in the stranding of fossil fuel resources worth just over \$100 trillion (Channell et al. 2015). This estimate applies current market prices of oil, gas, and coal $^{3}$ to the quantities of unburnable reserves estimated by McGlade and Ekins. This approach has the effect of using a discount rate of zero, applying 40-year analytic time frame running from 2010 to 2050 , and valuing only reserves rather the more expansive category of resources.

\section{Methodology}

\section{Attributes of a sound method to estimate the Carbon Ask}

A credible estimate of the Carbon Ask requires several important analytic components. First, it should consider all fossil fuel resources, not just reserves. Reserves represent resource quantities, the existence of which has been confirmed by sitespecific geologic investigations and for which extraction is

\footnotetext{
${ }^{3} \$ 70$ per barrel of oil, $\$ 6.50$ per million BTU, and $\$ 70$ per ton of coal.
}

technologically feasible, permitted by law, and commercially profitable at current prices. Resources, on the other hand, refer to the total quantity of fossil fuels that remain beneath the earth's surface. (Reserves are a subset of resources.) Some resources cannot be recovered with today's technologies; no matter how much money someone is willing to spend, they cannot extract the resource. After excluding unrecoverable resources, the result is technically recoverable resources.

Reserves are continually replenished as fossil fuels move out of the category of resources, into the narrower category of reserves, and then into production. For example, global reserves of oil grew from 643 billion barrels in 1980 to 1656 billion barrels in 2014, while natural gas reserves went from 2592 to 6973 trillion $\mathrm{ft}^{3}$ (EIA 2014b). For three decades, the ratio of oil reserves to oil production in the USA has oscillated between 9 and 14 years (EIA 2014c). The fact that reserves have increased over time and that the reserves-to-production ratio has not trended downward, is evidence that reserves are not an appropriate measure of a shrinking non-renewable resource. In addition, leaving nonreserve resources out of the Carbon Ask assigns these resources zero value. But because these resources are the source, first of reserves and then of production, they are clearly valuable. Shifting the focus from reserves to technically recoverable resources also has profound implications for the size of Carbon Ask because we estimate that - at a minimum - oil and natural gas resources exceed reserves by a factor of, respectively, 2.9 and 2.4.

Second, the estimation of the Carbon Ask should not be constrained by an unduly short time frame. Fossil fuel production is certain to continue for decades, perhaps centuries. Even though the time value of money (i.e., the discounting process) means that fossil fuel production in the future has less value than today, expected revenues from future production nonetheless contribute to today's resource values. Because fossil fuels are a finite resource, however, the analysis ought to constrain production quantities to total underground technically recoverable resources. In addition, because not all fossil fuels are used for energy production (e.g., oil is used as a feedstock by the chemical industry), this constraint also needs to reflect that some underground resources will go to non-energy uses, irrespective of climate policy.

Third, the estimated Carbon Ask should reflect the fact that intrinsic differences among fossil fuels in their carbon content and production costs will drive the mix of fuels used in a carbon-constrained world. For example, using natural gas to generate $1 \mathrm{~kW}$ h of electricity releases $1.21 \mathrm{lb}$ of $\mathrm{CO}_{2}$ while the use of coal releases around 2.13 lb (EIA 2015c). Production costs also vary widely. The typical production cost for conventional, onshore oil in the Middle East is about \$27 per barrel but about $\$ 65$ a barrel for unconventional North 
American shale fields (Weissmann 2014). ${ }^{4}$ Given differences in emission rates and production costs, rather than an across-the-board cut in all fossil fuel use, compliance with climate policy will resemble a least-cost optimization in which markets allocate the emission reductions across all fuel types and across the geographic locations of individual fuel types. ${ }^{5}$

Finally, instead of focusing only on the profits of fossil fuel producers (i.e., price minus cost, times quantity), a more complete measure of the Carbon Ask would assess total revenue (i.e., price times quantity). Revenue is a superior measure to profits for our purposes because it better approximates the impact of the Carbon Ask upstream in the supply chain (i.e., as experienced by asset owners, equipment suppliers, service companies, and workers in the fossil fuel industry). ${ }^{6}$ In the standard microeconomic framework, the supply-side impacts of policy actions are typically assessed only by a change in what economists call "producer surplus" which in this case would be the difference between the price of, say, a barrel of oil (inclusive of a premium, or rent, arising from its nonrenewable nature) and the marginal cost of producing it. Implicit in the standard model is the assumption that the capital and labor resources displaced by government policy would be re-deployed to other productive uses and thus do not constitute a true cost to society.

For this analysis, however, we look at the world's fossil fuel enterprise not through the lens of traditional microeconomics but through the broader lens of political economy. We aim to explain political resistance to climate policy, to displacement of industry incumbents, and to diffusion of new climate-friendly technologies. The question here is thus whether such resistance arises only when stakeholders face a threat to their ability to earn rents and producer surplus or, alternatively, when any aspect of their economic interests are threatened. We believe the latter case to be true. It seems selfevident that it is of only minimal comfort to workers who may lose their jobs and to corporate executives and owners facing significant decreases in their business to know that their resources would be productively re-deployed elsewhere in a

\footnotetext{
${ }^{4}$ Variation in production costs will also affect how the Carbon Ask gets distributed across the fossil fuel supply chain. Lower production costs mean that the Ask will be higher for asset owners (who take as profits the difference between price and cost), while high production costs imply that the firms and workers doing the production will experience a larger share of the Carbon Ask. Variability in production costs does not, however, change the aggregate estimate of the Ask.

${ }^{5}$ Geopolitical considerations, and attempts at market manipulation, may impede a least-cost allocation of production by markets. Nonetheless, production costs and carbon content would still play a role in the trajectory of prices and quantities.

${ }^{6}$ This approach is still incomplete because it does not capture the gains experienced downstream by the purchasers of fossil fuels who extract value in excess of the purchase price, a concept that economists refer to as consumer surplus. Given available data, we are not able to easily measure this downstream economic value.
}

post-policy world. Their propensity to politically resist policy change would seem to be driven primarily by the pain of short-term economic displacement and the risk that their personal well-being could be lower in a post-policy world.

\section{Quantifying the Carbon Ask}

The monetary value of the Carbon Ask (A) is defined as,

$A=V_{\mathrm{BAU}}-V_{2}{ }^{\circ} \mathrm{C}$

where $V_{\mathrm{BAU}}$ is the value of total existing subsurface fossil fuel resources recoverable with current technology (i.e., business as usual) and $V_{2}{ }^{\circ} \mathrm{C}$ is the value of only those resources that can be extracted and burned without exceeding the $2{ }^{\circ} \mathrm{C}$ temperature goal. We further decompose Eq. (1) into its two constituent parts,

$V_{\mathrm{BAU}}=\sum_{i=1}^{100} \frac{\left[Q_{\mathrm{TOi}} \cdot P_{\mathrm{TOi}}\right]+\left[Q_{\mathrm{TGi}} \cdot P_{\mathrm{TGi}}\right]+\left[Q_{\mathrm{TCi}} \cdot P_{\mathrm{TCi}}\right]}{(1+r)^{i}}$ and

$V_{2}{ }^{\circ} \mathrm{C}=\sum_{i=1}^{100} \frac{\left[Q_{\mathrm{BOi}} \cdot P_{\mathrm{BOi}}\right]+\left[Q_{\mathrm{BGi}} \cdot P_{\mathrm{BGi}}\right]+\left[Q_{\mathrm{BCi}} \cdot P_{\mathrm{BCi}}\right]}{(1+r)^{i}}$

where a 100 -year period serves as an arbitrary, but intentionally long, time frame to ensure that the most important cost impacts are captured ${ }^{7}$ and $r$ is the discount rate. Implicit in Eqs. (2) and (3) is the standard assumption made in the fields of finance and microeconomics that an asset's value equals the present value of the benefit stream emanating from it over time. $Q_{\mathrm{T}}$ is the total subsurface quantity of each resource type - oil $(O)$, natural gas $(G)$, and coal $(C)$ - that would be extracted in year $i$ in a world not constrained by climate policy. The three $P_{\mathrm{T}}$ terms are the market price in year $i$ for oil, gas, and coal in the unconstrained case.

The structure of Eq. (3) is similar to that of Eq. (2), except that the three $Q_{\mathrm{B}}$ terms and the three $P_{\mathrm{B}}$ terms are estimated based on the impact of a strong climate policy regime. Because we suppose a climate policy that reduces demand for fossil fuels (rather than constraining supply), both prices and quantities would be lower in Eq. (3) than they are in Eq. (2). The three $Q_{\mathrm{T}}$ and $Q_{\mathrm{B}}$ terms are each further individually constrained such that the cumulative quantity over time for each fuel type cannot exceed the total technically recoverable subsurface resource (less a reserve for non-energy uses). In short, the structure of Eq. (3) is the same as for Eq. (2), except that the latter reflects the price and quantity effects of a different policy regime.

\footnotetext{
${ }^{7}$ At discount rates of 3.00 and $9.42 \%$ - the two rates used in this papera cost of $\$ 1.00$ incurred 100 years from now has, respectively, a present value of about $\$ 0.05$ and $\$ 0.0001$. Costs incurred more than 100 years in the future thus have a minimal impact on our results.
} 
Century-long forecasts are of course subject to substantial uncertainties. The prices and quantities of fossil fuels used annually between today and 2115 will surely differ from what we have assumed in this analysis. Such differences do not, however, undermine the validity of our result. Our intent is not to omnisciently compute the "right" value of the Carbon Ask which, with hindsight in 2115 , will be seen as an accurate match to historical reality. ${ }^{8}$ Because we are interested in today's political dynamic, we just have to be "right" about what key players think the value of the Carbon Ask is today and how pending climate policies will affect their economic wellbeing. Like these stakeholders, we have no choice but to apply reasonable assumptions to the available data in order to measure the Carbon Ask.

\section{Calibrating the Carbon Ask}

We first calibrate Carbon Ask against the value of each fossil fuel type under the unconstrained, business-as-usual scenario,

$F_{\mathrm{x}}=\frac{A_{\mathrm{x}}}{V_{\mathrm{BAUx}}}$

where $F_{\mathrm{x}}$ is the fraction of the asset value for resource type $x$ (oil, gas, or coal) lost to the Carbon Ask. We then calibrate the Ask in economic terms,

$I_{\mathrm{E}}=\frac{A}{G D P}$

where $I_{\mathrm{E}}$ is the economic impact of the Carbon Ask, $A$ is the Carbon Ask in monetary terms, and GDP is global gross domestic product. Finally, we compute how much of each resource is left unused during the 100-year analytic period and express that quantity as the fraction of the resource that would have been used over 100 years in the absence of climate policy,

$I_{\mathrm{X}}=\sum_{i=1}^{100} Q_{\mathrm{TXi}}-Q_{\mathrm{BXi}}$ and

$U_{\mathrm{X}}=\frac{I_{\mathrm{X}}}{\sum_{i=1}^{100} Q_{\mathrm{TXi}}}$

where $I_{\mathrm{X}}$ is the impact of the Carbon Ask for resource type $x$ (oil, gas, or coal) in natural units and $U_{\mathrm{X}}$ is the fraction of the resource that remains unproduced. The $Q_{\mathrm{TX}}$ and $Q_{\mathrm{BX}}$ terms are as defined above.

\footnotetext{
${ }^{8}$ While 100 years of price and quantity data will be available in 2115 , there still would not be any historical data about a counterfactual world in which an alternative policy regime had existed.
}

\section{Data}

\section{Estimated total resources}

Our approach to estimating existing quantities of oil, natural gas, and coal is described in the Technical Appendix. By way of summary, we did not collect any original information but relied primarily on data from government agencies such as the US Geological Survey (USGS) and the German Federal Institute for Geosciences and Natural Resources (BGR). We included estimates of conventional resources and unconventional resources (such as shale gas and tight oil) and estimates of proved reserves and of technically recoverable resources. Reserve estimates tend to be point estimates based on sitespecific analyses, while estimates of yet-undeveloped resources tend to be the result of probabilistic modeling that projects the likelihood of discovering fossil fuel resources in locations around the world as a function of geological conditions. When quantities have been estimated probabilistically, we use the mean value from each distribution to estimate resources in the analyzed location. In addition, some fossil fuels support non-energy uses (e.g., as feedstocks in the chemical industry), and we assume that $8.02,1.71$, and $0.02 \%$ of, respectively, oil, gas, and coal resources will go to such uses (Heede and Oreskes 2016). Finally, it is also important to note that credible global data on coal resources are far sparser than for oil and gas; we had to make a number of simplifying assumptions when deriving our estimates of coal resources. For reasons outlined in the Technical Appendix, the estimates shown in Table 1 are lower bound estimates, with actual "realworld" quantities likely higher.

\section{Fossil fuel price and quantity trajectories}

Projections of fossil fuel prices and quantities reflect work done by the IEA which uses its World Energy Model (described in Box 1) to inform annual analyses of global energy issues. Its 2015 World Energy Outlook includes projections of prices and quantities through 2040 under alternative policy scenarios. IEA's projections assume annual GDP growth of $3.5 \%$ from 2013 to 2040 and annual population growth of $0.9 \%$ (IEA 2015b, pp. 37, 40). The IEA model simulates the impact of emerging energy technologies and "a process of technology learning" but does not assume "technological

Table 1 Estimated global quantities of technically recoverable resources available for energy use

\begin{tabular}{lll}
\hline Oil (billion barrels) & Natural gas (trillion $\mathrm{m}^{3}$ ) & Coal (billion t) \\
\hline 4436 & 465 & 8934 \\
\hline
\end{tabular}


breakthroughs which are as yet only aspirations" (IEA 2015a, pp. 43, 106).

\section{Box 1}

The International Energy Agency's World Energy Model (WEM)

The model is a large-scale simulation tool [that] consists of three main modules covering final energy consumption (including industry, transport, buildings, agriculture, and non-energy use), fossil fuel and bioenergy supply, and energy transformation (including power and heat generation, oil refining, and other transformation). The primary outputs from the model for each region are energy demand and supply by fuel, investment needs, and $\mathrm{CO}_{2}$ emissions The WEM is a very data-intensive model that covers the entire global energy system. The current version models global energy demand on the basis of 25 distinct regions, 13 of which are individual countries. Global oil and gas supply is modeled based on 120 distinct countries and regions; global coal supply is modeled based on 31 countries and regions. Most of the historic data on energy demand, supply, and transformation, as well as on energy prices, are obtained from IEA databases of energy and economic statistics. These are supplemented by additional data from many external sources (IEA 2015b, pp. 32-33).

Of interest are two IEA scenarios: the Current Policies Scenario (CPS), which reflects "business as usual" and incorporates policies implemented as of mid-2015, and the 450 Scenario (450S), which assumes a set of policies that keep greenhouse gas emissions to a level that yields a $50 \%$ chance of holding warming to the $2{ }^{\circ} \mathrm{C}$ goal (IEA 2015a, p. 106; IEA 2015b, p. 34). We take IEA's CPS to be equivalent to our business-as-usual (BAU) case and IEA's $450 \mathrm{~S}$ to be equivalent to our $2{ }^{\circ} \mathrm{C}$ case.

The policy objective in IEA's 450 Scenario is a demanddriven reduction in fossil fuel use. IEA assumes that a high $\mathrm{CO}_{2}$ price under $450 \mathrm{~S}$ will stimulate substantial growth in low-carbon electricity generation, much higher energy efficiency, and significant electrification of the world's passenger vehicle fleet (IEA 2015a, p. 109). ${ }^{9}$ Fossil fuel subsidies are phased out by 2040 everywhere except the Middle East (IEA 2015a, p. 33). The $\mathrm{CO}_{2}$ price in 2040 is $\$ 140$ per ton in all major economies, except China, Russia, Brazil, and South Africa, where the price is $\$ 125$. Under CPS, only the EU and Korea are simulated to price carbon in 2040 (at \$40) and then only in certain sectors (IEA 2015b, p. 42).

To derive annual prices and quantities, we took several steps. We used the IEA estimates for prices and quantities for 2020, 2030, and 2040. For current production levels, IEA's estimates of gas and coal quantities are for 2013, while data for oil are for 2014. To ensure temporal consistency, we used the BP Statistical Review for 2014 quantity data for coal and gas (BP 2015). We used IEA data for the 2014 price of gas and coal, but owing to the steep decline in oil prices starting in

\footnotetext{
${ }^{9}$ By contrast, a supply-side policy mechanism would force resource owners to curtail extraction. In the absence of price controls, a supplyside policy would create artificial scarcity, increasing prices and creating windfall profits for some owners.
}

late 2014, we used updated data for current oil prices. We took the average of European Brent spot oil prices from January to October 2015 (EIA 2015b), deflated to 2014 dollars (Federal Reserve 2015). Finally, to facilitate projections beyond the end of IEA's 2040 analytic end-date, we computed the annual linear growth rate for prices and quantities between 2030 and 2040. Our results are summarized in Table 2.

Using the estimates from Table 2, we constructed annual estimates of prices and quantities under both policy scenarios. Linear interpolation was used for the years in the 2015 to 2020, 2020 to 2030, and 2030 to 2040 intervals. For years after 2040, we applied the linear annual growth rate from 2030 to 2040. This simplification of a complex reality was necessary because sophisticated simulations over longer time frames are not available in the public domain. As explained below, we conducted sensitivity analyses to assess how this extrapolation of post-2040 quantities affected our results. Prices are expressed in 2014 dollars. The 100-year analytic time frame runs from 2016 to 2115.

\section{Other data}

To compute the present value of the stream of revenues from fossil fuel production, we analyzed two discount rates. We used $3.00 \%$ as a risk-free discount rate that might be used by a risk-neutral government policymaker investing on behalf of a large number of taxpayers (U.S. Office of Management and Budget 2003). The choice of a $9.42 \%$ rate reflects the weighted average cost of capital for five global industrial sectors related to coal, oil, and gas. If each sector is weighted based on the global number of firms in it, the overall cost of capital is $9.42 \%$ (Damodaran 2015).

To capture the different cost of capital for governments and private firms, we applied the lower $(3.00 \%)$ rate to government-owned fossil fuel resources and the higher $(9.42 \%)$ rate to privately held assets. Data on ownership appear to exist only for proved reserves; we assume that the ownership shares of non-reserve resources are the same as for reserves. Based on Heede and Oreskes, we estimate that $91.3 \%$ of oil resources, $91.0 \%$ of gas resources, and $89.7 \%$ of coal resources are owned by governments (2016). We use these percentages as weights to compute a weighted average of the Carbon Ask under the two discount rates. ${ }^{10}$ To compute Eq. (5), we used an exchange-rate-based global GDP of \$77.869 trillion in 2014 (World Bank 2015).

Table 3 summarizes our approach and contrasts it with the analyses done by others described above.

\footnotetext{
${ }^{10}$ The result is equivalent to applying a single discount rate of $3.18 \%$.
} 
Table 2 Price $(\mathrm{P})$ and quantity $(\mathrm{Q})$ trajectories

\begin{tabular}{|c|c|c|c|c|c|c|c|c|c|c|c|c|}
\hline & \multicolumn{4}{|l|}{ Crude oil } & \multicolumn{4}{|l|}{ Natural gas } & \multicolumn{4}{|l|}{ Coal } \\
\hline & \multicolumn{2}{|l|}{ BAU } & \multicolumn{2}{|l|}{$2^{\circ} \mathrm{C}$} & \multicolumn{2}{|l|}{ BAU } & \multicolumn{2}{|l|}{$2{ }^{\circ} \mathrm{C}$} & \multicolumn{2}{|l|}{ BAU } & \multicolumn{2}{|l|}{$2{ }^{\circ} \mathrm{C}$} \\
\hline & $\begin{array}{l}\text { Q million } \\
\text { barrels }\end{array}$ & $\begin{array}{l}\text { P 14\$/ } \\
\text { barrel }\end{array}$ & $\begin{array}{l}\text { Q million } \\
\text { barrels }\end{array}$ & $\begin{array}{l}\text { P } 14 \$ / \\
\text { barrel }\end{array}$ & $\begin{array}{l}\mathrm{Q} \\
\text { billion } \mathrm{m}^{3}\end{array}$ & $\begin{array}{l}\text { P } 14 \$ / \\
\text { million } \\
\text { BTU }\end{array}$ & $\begin{array}{l}\mathrm{Q} \\
\text { billion } \mathrm{m}^{3}\end{array}$ & $\begin{array}{l}\text { P } 14 \$ / \\
\text { million } \\
\text { BTU }\end{array}$ & $\begin{array}{l}\mathrm{Q} \\
\text { million } \mathrm{t}\end{array}$ & $\begin{array}{l}P \\
14 \$ / t\end{array}$ & $\begin{array}{l}\mathrm{Q} \\
\text { million } \mathrm{t}\end{array}$ & P $14 \$ / t$ \\
\hline 2014 & 33,611 & $\$ 54$ & 33,611 & $\$ 54$ & 3393 & $\$ 9.10$ & 3393 & $\$ 9.10$ & 5545 & $\$ 78$ & 5545 & $\$ 78$ \\
\hline 2020 & 35,588 & $\$ 83$ & 34,201 & $\$ 77$ & 3914 & $\$ 7.74$ & 3770 & $\$ 7.26$ & 6040 & $\$ 99$ & 5360 & $\$ 80$ \\
\hline 2030 & 39,165 & $\$ 130$ & 30,624 & $\$ 97$ & 4766 & $\$ 11.13$ & 3922 & $\$ 8.89$ & 7033 & $\$ 115$ & 4463 & $\$ 79$ \\
\hline 2040 & 42,742 & $\$ 150$ & 27,047 & $\$ 95$ & 5617 & $\$ 12.51$ & 4073 & $\$ 8.63$ & 8026 & $\$ 123$ & 3565 & $\$ 77$ \\
\hline $\begin{array}{l}\text { Yearly change } \\
\quad(2030-2040)\end{array}$ & 357.7 & $\$ 2.00$ & -357.7 & $-\$ 0.20$ & 85.2 & $\$ 0.14$ & 15.2 & $-\$ 0.03$ & 99.3 & $\$ 0.80$ & -89.8 & $-\$ 0.20$ \\
\hline
\end{tabular}

\section{Sensitivity analyses}

In addition to our base case, we conducted five sensitivity analyses to explore the importance of three elements of our methodology. First, to understand the impact of linear extrapolation of prices and quantities (based on the period from 2030 to 2040) to project prices and quantities from 2041 to 2115 , we applied an exponential growth rate (again based on the 2030 to 2040 period) to simulate post-2040 values and, in another sensitivity analysis, simulated no change in prices and quantities in 2041 and beyond (i.e., these values are held at their 2040 levels). Second, to understand the impact of using a 100 -year time frame for the analysis, we evaluated both a 25 -year and a 150 -year time frame. Finally, to understand the impact of our choice to measure the Carbon Ask based on all resources (i.e., reserves plus non-reserve resources), we conducted a sensitivity analysis in which production is limited to proved reserves.

\section{Results}

\section{Results of primary analysis}

Table 4 indicates that, with blended public/private sector discount rates, the value of subsurface fossil fuel resources in a business-as-usual case is about $\$ 295$ trillion. In a world constrained by climate policy, the value of those resources drops to about $\$ 110$ trillion, a decrease of $\$ 185$ trillion, or $63 \%$. In dollar terms, the Ask is largest for oil ( $\$ 127.5$ trillion) while, as a percentage reduction in current values, it is largest for coal $(75 \%)$. As shown in Table 5, the total Ask is equivalent to 2.38 years of global GDP, with most of the Ask originating in oil (1.64 years), with the remainder in gas and coal (at 0.43 and 0.31 years, respectively). Table 6 demonstrates that about 58,3 , and $82 \%$ of, respectively, the oil, gas, and coal resources that would otherwise have been produced over the next 100 years would likely remain unburned under a $2{ }^{\circ} \mathrm{C}$ climate policy.

Table 7 provides data about the year in which production is simulated to come to an end, under both the BAU and $2{ }^{\circ} \mathrm{C}$ cases. Use of oil, for example, ends in 2102 under the BAU case because cumulative production reaches our estimate of total subsurface resources while use ends in 2115 in the $2{ }^{\circ} \mathrm{C}$ case because demand drops to zero.

\section{Results of sensitivity analyses}

Table 8 provides the results of the sensitivity analyses. The exponential approach to estimating post-2040 prices and quantities causes the Carbon Ask to increase from $\$ 185$ trillion to $\$ 203$ trillion, while the fixed price assumption causes the Ask to drop to $\$ 112$ trillion. Although the difference among these three cases is substantial, we believe that even the lower value of $\$ 112$ trillion is still so large that our core conclusion remains valid. Truncating the analysis at 25 years (which avoids the question of how to extrapolate IEA's results beyond its modeling period) causes the Carbon Ask to drop dramatically, to $\$ 39$ trillion. While this is an interesting result, we do not attach much practical importance to it. In the absence of climate policy, fossil fuel production is almost certain to continue for many decades, if not a century or more. Ending the analysis in 2040 effectively assigns no value to fossil fuels produced after that date, a result that is not realistic. When it comes to the 150-year sensitivity case, the Ask increases from $\$ 185$ trillion to $\$ 189$ trillion, but in comparative terms, this is a small increase.

The final sensitivity explores the consequences of limiting the analysis to only proved reserves. Given this assumption, the world would run out of resources sooner. For example, in the BAU scenario, oil production ends in 2051 (when proved resources are simulated to be exhausted) rather than in 2102 as in our base case. As described previously, however, we believe that it is a mistake to focus only on proved reserves 


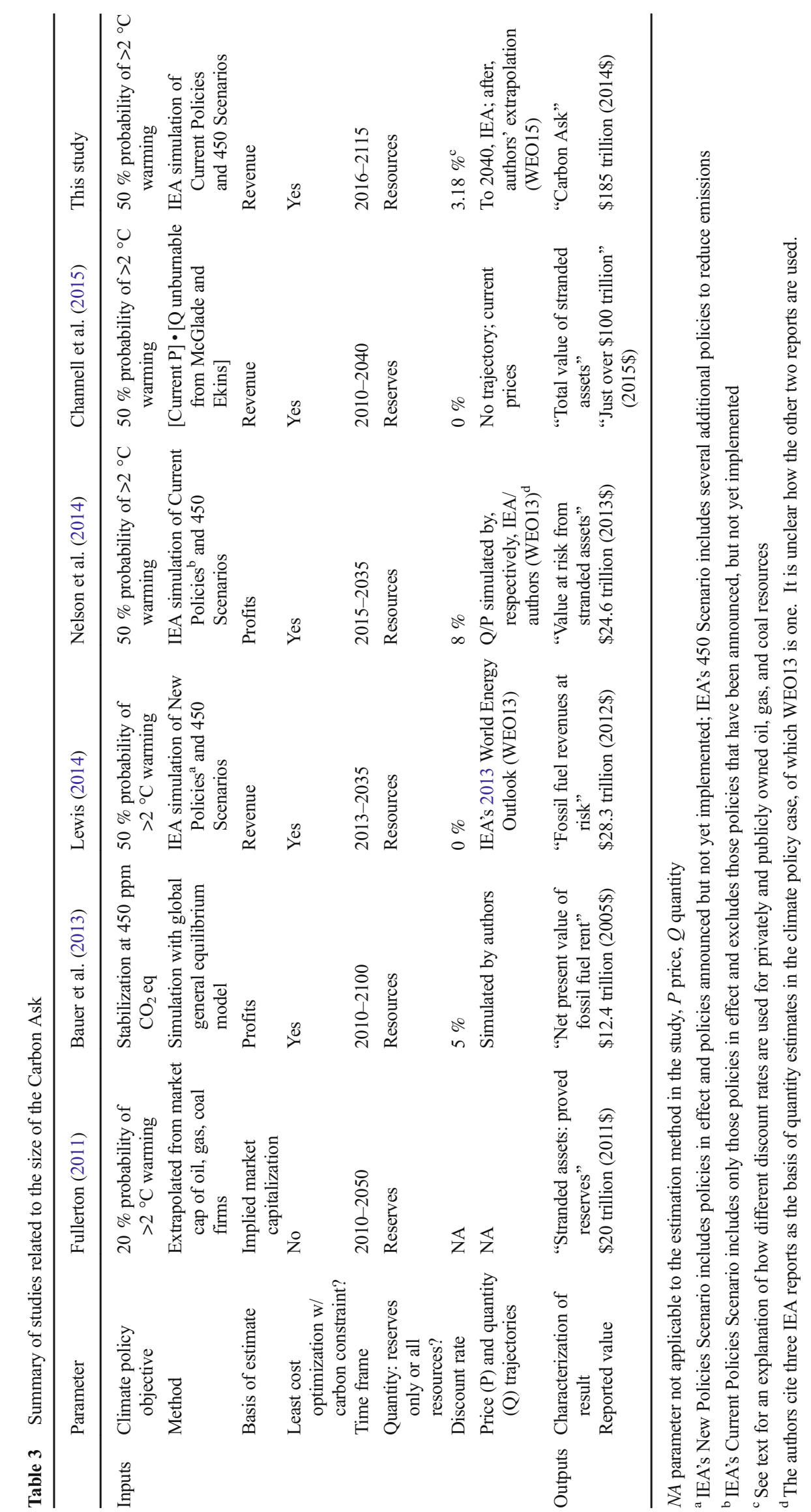


Table 4 The size of the Carbon Ask

\begin{tabular}{|c|c|c|c|c|}
\hline \multicolumn{5}{|c|}{ Value of subsurface resource-BAU scenario ( $2014 \$$ million $)$} \\
\hline Discount rate & Oil & Gas & Coal & Total \\
\hline $3.00 \%$ & $\$ 208,219,123$ & $\$ 75,026,297$ & $\$ 34,390,281$ & $\$ 317,635,700$ \\
\hline Blended case & $\$ 193,931,475$ & $\$ 69,849,510$ & $\$ 31,638,929$ & $\$ 295,419,914$ \\
\hline $9.42 \%$ & $\$ 43,993,288$ & $\$ 17,506,450$ & $\$ 7,678,122$ & $\$ 69,177,861$ \\
\hline \multicolumn{5}{|c|}{ Value of subsurface resource $-2{ }^{\circ} \mathrm{C}$ scenario ( $2014 \$$ million $)$} \\
\hline Discount rate & Oil & Gas & Coal & Total \\
\hline $3.00 \%$ & $\$ 70,143,687$ & $\$ 38,380,194$ & $\$ 8,291,903$ & $\$ 116,815,783$ \\
\hline Blended case & $\$ 66,412,431$ & $\$ 36,011,069$ & $\$ 7,850,327$ & $\$ 110,273,827$ \\
\hline $9.42 \%$ & $\$ 27,255,687$ & $\$ 12,056,587$ & $\$ 4,004,758$ & $\$ 43,317,032$ \\
\hline \multicolumn{5}{|c|}{ Carbon Ask (2014\$ million) } \\
\hline Discount rate & Oil & Gas & Coal & Total \\
\hline $3.00 \%$ & $\$ 138,075,435$ & $\$ 36,646,103$ & $\$ 26,098,379$ & $\$ 200,819,917$ \\
\hline Blended case & $\$ 127,519,044$ & $\$ 33,838,441$ & $\$ 23,788,602$ & $\$ 185,146,087$ \\
\hline $9.42 \%$ & $\$ 16,737,601$ & $\$ 5,449,863$ & $\$ 3,673,364$ & $\$ 25,860,828$ \\
\hline \multicolumn{5}{|c|}{ Carbon Ask as $\%$ of value in BAU scenario } \\
\hline Discount rate & Oil & Gas & Coal & Total \\
\hline $3.00 \%$ & $66 \%$ & $49 \%$ & $76 \%$ & $63 \%$ \\
\hline Blended case & $66 \%$ & $48 \%$ & $75 \%$ & $63 \%$ \\
\hline $9.42 \%$ & $38 \%$ & $31 \%$ & $48 \%$ & $37 \%$ \\
\hline
\end{tabular}

because substantial economic value is ultimately realized from non-reserve resources as they become first proved reserves and then produced resources. Even if one wishes to consider only proved reserves, a Carbon Ask of \$71 trillion-roughly equivalent to a year of global GDP — is still an extraordinarily large number.

\section{Key limitations}

Our results should be interpreted in light of several analytic limitations. First, although the price and quantity trajectories through 2040 come from IEA's sophisticated modeling, post2040 quantities reflect simple linear extrapolation. While our sensitivity analyses suggest that the extrapolation method does have a material effect on our results, even the lowest value for the Carbon Ask (\$112 trillion) is still quite large. What's more, our objective is not to compute a value for the Carbon Ask that will be proven historically correct in 2115; instead, because we aim to explain today's political dynamics, we only need to make an estimate that can reasonably be said

Table 5 Carbon Ask relative to 2014 global GDP of $\$ 77.869$ trillion

\begin{tabular}{lllll}
\hline Discount rate & Oil & Gas & Coal & Total \\
\hline $3.00 \%$ & 1.77 & 0.47 & 0.34 & 2.58 \\
Blended case & 1.64 & 0.43 & 0.31 & 2.38 \\
$9.42 \%$ & 0.21 & 0.07 & 0.05 & 0.33 \\
\hline
\end{tabular}

to match the likely calculations of stakeholders potentially affected by decarbonization of the world's economy.

A second consideration is that we calculate the Carbon Ask based on the single, demand-side, climate policy embedded in the IEA 450 Scenario. This scenario represents an aggressive approach to reduce demand for fossil fuels with substantial technological innovation and imposition of a high price on carbon. If policymakers enact more timid policies or if technological innovation proceeds more slowly, then more fossil fuels will be used, and will likely command a higher price, than would otherwise be the case. In turn, we will have overestimated the size of the Carbon Ask. On the other hand, IEA's 450 Scenario is built on a carbon budget that reflects a $50 \%$ probability of staying within the $2{ }^{\circ} \mathrm{C}$ target. Many policy debates, however, have focused on a $66 \%$ chance of achieving the target which, in turn, corresponds to a $23 \%$ smaller carbon budget. If policymakers implement demand-side policies to stay within the smaller carbon budget, then the Carbon Ask estimated here is too low. Finally, if policymakers implement supply-side measures (e.g., a prohibition or other constraint on fossil fuel production), price and quantity

Table 6 Calibrating the Carbon Ask

\begin{tabular}{lll}
\hline Fuel & $\begin{array}{l}\text { Quantity not produced } \\
2016-2115\end{array}$ & $\begin{array}{l}\text { Portion of quantity } \\
\text { not produced }\end{array}$ \\
\hline Oil & 2.58 trillion barrels & $58.2 \%$ \\
Gas & 12.82 trillion $\mathrm{m}^{3}$ & $2.8 \%$ \\
Coal & 871.27 billion $\mathrm{t}$ & $81.6 \%$ \\
\hline
\end{tabular}


Table 7 Final year of production/reason for end of production

\begin{tabular}{lll}
\hline Resource & BAU & $2{ }^{\circ} \mathrm{C}$ \\
\hline Oil & $2102 /$ & $2115 /$ \\
& Cumulative production reaches estimated quantity of subsurface resource & Negligible demand \\
Natural gas & $2085 /$ & Not applicable - production continues beyond 2115 \\
& Cumulative production reaches estimated quantity of subsurface resource & \\
Coal & Not applicable - production continues beyond 2115 & $2079 /$ \\
& & Negligible demand \\
\hline
\end{tabular}

trajectories could be markedly different, as artificial scarcity causes prices to rise, thereby creating windfalls for some producers and effectively shutting down others. It is not, however, particularly important that we accurately forecast the trajectory of climate policy over the next 100 years; instead, as long as the IEA 450 Scenario captures reasonable expectations on the part of today's stakeholders about the likely character of climate policy, then our results remain valid as means of understanding today's political dynamics.

Third, as explained in the Technical Appendix, our estimate of the existing subsurface quantities of fossil fuels is almost certainly an underestimate. Large portions of the globe have not been assessed for the presence of unconventional resources (such as tight oil and shale gas). To the extent that such resources exist in large quantities, then a strong climate policy would hinder their production, thereby increasing the size of the Carbon Ask. In addition, we omitted methane hydrates from our analysis even though some experts believe that there is much more natural gas in hydrates than in any other type of resource (IEA 2013; Rogner 2012). We omit methane hydrates because production has yet to be proven commercially viable (Rogner 2012; Whitney et al. 2009) and because credible data are sparse. If commercial production of methane hydrates becomes feasible, however, then the Carbon Ask could be appreciably higher than we have estimated.

Table 8 Summary of modeling results: base case and sensitivities

\begin{tabular}{|c|c|c|c|c|}
\hline Case & $\begin{array}{l}\text { Length } \\
\text { of } \\
\text { analysis } \\
\text { period }\end{array}$ & $\begin{array}{l}\text { Post- } 2040 \\
\text { price and } \\
\text { quantity } \\
\text { extrapolation } \\
\text { method }\end{array}$ & $\begin{array}{l}\text { Cap on } \\
\text { quantity of } \\
\text { subsurface } \\
\text { fossil fuel }\end{array}$ & $\begin{array}{l}\text { Carbon } \\
\text { Ask-2014\$ } \\
\text { million (blended } \\
\text { public/private } \\
\text { discount rates) }\end{array}$ \\
\hline Base & 100 & Linear & Resource & $\$ 185,146,087$ \\
\hline Sensitivity & 100 & Exponential & Resource & $\$ 202,702,261$ \\
\hline Sensitivity & 100 & $\begin{array}{l}\text { Fixed at } 2040 \\
\text { values }\end{array}$ & Resource & $\$ 112,348,929$ \\
\hline Sensitivity & 25 & $\begin{array}{l}\text { Not } \\
\quad \text { applicable }\end{array}$ & Resource & $\$ 38,563,190$ \\
\hline Sensitivity & 150 & Linear & Resource & $\$ 189,203,484$ \\
\hline Sensitivity & 100 & Linear & Reserve & $\$ 71,205,314$ \\
\hline
\end{tabular}

\section{Discussion}

\section{The nature of the Carbon Ask}

At $\$ 185$ trillion, the Carbon Ask is a substantial sum by any measure. It represents 2.4 times annual global GDP and a $63 \%$ deterioration in the value of fossil fuel assets which, in a world not constrained by climate policy, are worth $\$ 295$ trillion. As with all long-term valuations, the discount rate has a significant effect. At $3.00 \%$, the Carbon Ask tops $\$ 200$ trillion, while at $9.42 \%$, it falls to \$26 trillion. Even this lower value, however, represents a $37 \%$ devaluation relative to the unconstrained asset value.

Our results confirm that the Carbon Ask can manifest in two different ways. The first is when resources are not produced, implying that the resource owner (and the firms and workers in its supply chain) lose the value of the foregone production. Even if some production occurs in a policyconstrained world, adverse impacts still occur if the price is less than it otherwise would have been. Both phenomena are present in our results. For example, in the case where oil production is not constrained by climate policy, about 4.4 trillion barrels are cumulatively produced at an average (undiscounted) price of $\$ 192$ per barrel during the 100-year simulation period. In the $2{ }^{\circ} \mathrm{C}$ case, however, only 1.9 trillion barrels are produced at average price of $\$ 85$ per barrel.

In addition, our results suggest that the impact of the Carbon Ask will be experienced differently across fuel types. In proportional terms, coal experiences the most significant effects, with $75 \%$ of its economic value, and $82 \%$ of its physical mass, being lost to the Ask. While oil suffers a smaller proportional deterioration in economic value (66\% versus coal's $75 \%$ ), it suffers a much larger impact in absolute terms (\$128 trillion versus $\$ 24$ trillion). This reflects the relative size of the two industries; the value of oil revenues in the BAU case ( $\$ 194$ trillion) is six times larger than the value for coal (\$32 trillion). Interestingly, at the end of the 100-year modeling period, only $3 \%$ of gas resources remain underground in the $2{ }^{\circ} \mathrm{C}$ case relative to the BAU case, yet the reduction in economic value for gas is $48 \%$. The reason for the discrepancy lies in pricing. Gas commands an average (undiscounted) price of $\$ 7.84$ per million BTU in $2{ }^{\circ} \mathrm{C}$ case but $\$ 13.74$ in the BAU case. 


\section{The role of technology incumbents}

Given the size of the Carbon Ask and the historical evidence on the politics of technological innovation, we would expect technology incumbents to exert political pressure to impede the transition to new technologies. Accordingly, we investigated industry reaction to the recently promulgated US Clean Power Plan (CPP) intended to reduce emissions from electric power plants - the country's single biggest source of $\mathrm{CO}_{2}$ (EPA 2016). In particular, the CPP requires states to reduce emissions from coal- and gas-fired power plants (EPA 2015). Implicit in the CPP is a hierarchy of preferred strategies: increased energy efficiency, more renewable energy, and use of gas in lieu of coal. Coal suffers under all three strategies, while natural gas suffers under the first two, but benefits from the third.

Because $67 \%$ of US electricity is generated with fossil fuels (EIA 2016), coal and natural gas are incumbent technologies. While non-hydropower renewable energy technologies (e.g., solar and wind) are increasing in scale, they are responsible for only $7 \%$ of electricity generation (EIA 2016) and can be viewed as technology innovations that challenge incumbent coal- and gas-powered generation.

Twenty-seven states have sued the Environmental Protection Agency (EPA) to block the rule's implementation (Environment \& Energy Publishing 2016). Data are also available, by state, on the presence of in-state coal and gas reserves (EIA 2015a; EIA 2014a). If the core premise of this paperthat subsurface fossil fuel resources motivate efforts to impede policy to address climate change - is correct, we would expect to see a correlation between the presence of oil and gas reserves and a state's decision to join the suit against EPA. As Table 9 demonstrates, such a pattern is indeed evident. If a state has coal reserves, it is more than twice as likely to have

Table 9 States' propensity to sue to block EPA's Clean Power Plan as explained by existence of in-state fossil fuel reserves

\begin{tabular}{|c|c|c|c|c|c|}
\hline & & & $\begin{array}{l}\text { Suing } \\
\text { EPA }\end{array}$ & $\begin{array}{l}\text { Not suing } \\
\text { EPA }\end{array}$ & Total \\
\hline \multirow{4}{*}{$\begin{array}{l}\text { State has coal } \\
\text { reserves? }\end{array}$} & \multirow[t]{2}{*}{ Yes } & Number & 22 & 11 & 33 \\
\hline & & Percent & $66.7 \%$ & $33.3 \%$ & $100.0 \%$ \\
\hline & \multirow[t]{2}{*}{ No } & Number & 5 & 13 & 18 \\
\hline & & Percent & $27.8 \%$ & $72.2 \%$ & $100.0 \%$ \\
\hline \multicolumn{6}{|l|}{$t=3.462 ; p=0.01$} \\
\hline & & & $\begin{array}{l}\text { Suing } \\
\text { EPA }\end{array}$ & $\begin{array}{c}\text { Not suing } \\
\text { EPA }\end{array}$ & Total \\
\hline \multirow{4}{*}{$\begin{array}{l}\text { State has gas } \\
\text { reserves? }\end{array}$} & \multirow[t]{2}{*}{ Yes } & Number & 14 & 3 & 17 \\
\hline & & Percent & $82.4 \%$ & $17.6 \%$ & $100.0 \%$ \\
\hline & \multirow[t]{2}{*}{ No } & Number & 13 & 21 & 34 \\
\hline & & Percent & $38.2 \%$ & $61.8 \%$ & $100.0 \%$ \\
\hline$t=2.840 ; p=0.01$ & & & & & \\
\hline
\end{tabular}

sued EPA to block the Clean Power Plan as a state with no coal reserves. A similar pattern holds for states with gas reserves. In both cases, the results are statistically significant at the 0.01 level.

Especially interesting is that fossil fuel interests have not limited their action to lobbying lawmakers and attempting to influence public opinion about the CPP but also appear to have activated the policy apparatus in these 27 states to take legal action on their behalf. Even as a first approximation of what is undoubtedly a complex phenomenon, this analysis provides evidence that fossil fuel incumbents are unlikely to surrender their markets without a fight. ${ }^{11}$ It also confirms that political action is correlated with, if not motivated by, the presence of fossil fuel resources (i.e., the focal point of the Carbon Ask). Finally, resistance by industry incumbents to the technological changes required by the CPP is consistent with historical patterns described by Balalaeva, Comin and Hobijn, and Mokyr.

\section{Technology transformation: market- or policy-driven?}

Especially over the past two centuries, technological innovation has been a central feature in economic development, with radical advances across sectors such as agriculture, transportation, chemicals, medicine, manufacturing, information technology, and telecommunications. At first glance, such examples might be taken as evidence of the practicality of achieving decarbonization of the world's energy sector. In most cases, however, these changes were not the intentional result of government policy but are examples of Schumpeter's "creative destruction" in which a new technology with superior performance and/or lower costs pushed aside an incumbent technology or business practice and succeeded in the market because it created superior value for its users.

We struggled to come up with historical examples of economic transformations that were both at the same scale as global decarbonization and the result of intentional government action. While there has been substantial environmental progress in the US and the EU when it comes to local air quality and water pollution, such waste management activities are not analogous to situations where governments intervene in large existing markets to purposively alter the types of goods being bought and sold in commercial transactions. There are some relevant precedents - the phaseout of ozone depleting substances and of certain pesticides such as DDTbut such cases were much smaller in scale than

\footnotetext{
${ }^{11}$ Interestingly, parties suing EPA over the CPP include not only several states but also multiple trade associations, coal companies, and at least three labor unions. Without a more detailed analysis, it is not possible to discern the degree to which specific components of the Carbon Ask, and its economic impacts, have motivated the specific political actions of these stakeholders.
} 
decarbonization would be (and depended on the availability of cost-effective substitutes).

While government campaigns to reduce tobacco consumption have enjoyed significant success, the US experiment with alcohol prohibition in the early twentieth century is widely regarded as a failed policy. One author-who treads lightly because of the freighted human rights issues - notes that decarbonization has economic parallels to the US abolition of slavery, the foundation of the eighteenth- and nineteenthcentury southern agricultural economy and the primary driver of the Civil War (Hayes 2014). While a more thorough historical analysis might yield other cases of policy-driven economic transformation, it seems important to appreciate the limited precedents for such action, especially given the foundational role that fossil fuel energy plays across the economy.

\section{Compensating entities facing the Carbon Ask}

Even if a sound climate policy passes a strict cost-benefit test where benefits exceed costs, the distribution of the costs and benefits of action will not align well across socioeconomic groups, industry groups, poor and rich countries, or producers and consumers. In short, there will be winners and losers, and those on the receiving end of the Carbon Ask will be among the losers. Because many of these actors are in a position to thwart policy changes, one wonders if there is a way to compensate them for their losses, so as to facilitate the process of decarbonization.

Compensating fossil fuel owners would not be easy. Granted, the standard microeconomic framework suggests that because the benefit of climate policy likely exceeds its cost, winners (i.e., those who escape the adverse consequences of climate change) could theoretically fully compensate losers (i.e., those who incur the costs of emission reductions). As a practical matter, however, such transfers are highly problematic. In addition to representing a massive redistribution of wealth on a global scale for which there are currently no legal or institutional mechanisms, unless the compensation scheme were universal, leakage could easily undermine its environmental benefit. If only some resource owners limit fossil fuel production, then production would likely migrate to other unconstrained resource owners, thereby enriching them at the expense of those owners who do limit production and also undermining the environmental benefit. The permanence of agreements to leave resources underground may also be suspect. Even if a resource owner agrees to cease production today, there may be little recourse if the owner later reneges on its commitment (especially if the resource owner is a sovereign state).

While international compensation mechanisms may be impractical, subnational policies may hold more promise. Transitional assistance to workers, communities, regions, and possibly even firms, adversely affected by deep reductions in fossil fuel production might serve two objectives: improving the welfare of those entities experiencing the Carbon Ask and potentially mitigating at least some of political opposition to strong climate policy. Financing for such transitional assistance could come from a price on carbon - either in the form of revenues generated by a carbon tax or through the government sale of emission allowances under a cap-and-trade program.

\section{Conclusion}

In a word, the Carbon Ask is enormous, and will be experienced by all those engaged in the global fossil fuel enterprise: firms, workers, consumers, communities, and governments. The historical record suggests that such groups - whose livelihoods and well-being depend on current technologies and ways of doing business - can be expected to use political power and the policymaking process to thwart the diffusion of new technologies that threaten their interests. A failure to recognize this reality only impedes the search for the kinds of compromises that will be needed to achieve meaningful action on climate change. We are reminded of Upton Sinclair's observation that "it is difficult to get a man to understand something, when his salary depends upon his not understanding it" (Sinclair 1935, p. 109).

Given the size of the Carbon Ask and the history of technological change over the past two centuries, achieving the G7's goal of decarbonizing the world's economy by 2100 seems possible only if either or both of two phenomena come to pass. First, sufficient technological innovation must occur so that low-carbon or carbon-free technologies can prevail over incumbent technologies in the marketplace by offering superior performance or lower price. Consider how competitive forces have triggered a spiral of innovation between the iPhone and Android phones that has consigned simple, flip phones to a tiny fraction of the market (at least in America). If clean technologies can similarly outcompete fossil-fuel technologies based on price and/or quality, then powerful market forces may negate the political power of industry incumbents over the long run. And, of course, a price on carbon, and an end to fossil-fuel subsidies, would help level the playing field.

An alternative - perhaps complementary - path forward lies in the policy world rather than the market place. In the same way that industry incumbents translate their economic power into political power, we might expect that as new technologies enjoy more economic success, there would be a commensurate increase in their political power (Meckling et al. 2015). Wind power, for example, has attracted at least some political support from policymakers who dispute the risks of global warming but embrace the economic benefits in their home jurisdictions (The Economist 2013). Increased political power for new technology providers, supplemented by the political power of engaged citizens, environmental interest 
groups, and those who stand to benefit from transitional aid to entities facing the Carbon Ask, could thus help mitigate the power of fossil fuel interests, not in the marketplace but in the halls of government.

Open Access This article is distributed under the terms of the Creative Commons Attribution 4.0 International License (http:// creativecommons.org/licenses/by/4.0/), which permits unrestricted use, distribution, and reproduction in any medium, provided you give appropriate credit to the original author(s) and the source, provide a link to the Creative Commons license, and indicate if changes were made.

\section{References}

Acemoglu D, Robinson J (2000) Political losers as a barrier to economic development. Polit Econ Gov Develop 90(2):126-130

Acemoglu D, Zilibotti F, Aghion P (2014) Distance to frontier, selection, and growth. J Eur Econ Assoc 4(1):37-74

Balalaeva D (2015) Political competition, agenda power, and incentives to innovate: an empirical examination of vested-interest theory. Rev Policy Res 32(4):413-442

Bauer N, Mouratiadou I, Luderer G, Baumstark L, Brecha R, Edenhofer O, Kriegler E (2013) Global fossil energy markets and climate change mitigation - an analysis with REMIND. Climatic Change. 1-14. doi:10.1007/s10584-013-0901-6

BP (2015) BP Statistical Review of World Energy, 64th edn. BP, PLC, London, UK

Channell J, Curmi E, Nguyen P P, Syme A, Jansen H, Rahbari E, Kruger T (2015) Energy Darwinism II. Citi GPS, London

Chaudhry A, Garner P (2007) Do governments suppress growth? Institutions, rent-seeking, and innovation blocking in a model of schumpeterian growth. Econ Polit 19(1):35-50

Comin D, Hobijn B (2009) Lobbies and technology diffusion. Rev Econ Stat 91(2):229-244

COP21 (2015) Paris Agreement. United Nations Framework Convention on Climate Change, Paris, France

Damodaran A (2015) Cost of equity and capital (updateable)., Retrieved from http://pages.stern.nyu.edu/ adamodar/

David P (1985) Clio and the Economics of QWERTY. Am Econ Rev Pap Proc 75(2):332-337

EIA (2014a) Dry natural gas proved reserves. Energy Information Administration, Washington, DC, Retrieved from http://www.eia. gov/dnav/ng/ng_enr_dry_a_epg0_r11_bcf_a.htm

EIA (2014b) US Department of Energy. Energy Information Administration, Washington, DC, International Energy Statistics, Retrieved July 6, 2015, from http://www.eia.gov/cfapps/ ipdbproject/IEDIndex3.cfm?tid=3\&pid=3\&aid=6

EIA (2014c) U.S. Total Crude Oil Proved Reserves, Reserves Changes, and Production. US Department of Energy. Energy Information Administration, Washington, DC, Retrieved August 8, 2015, from http://www.eia.gov/dnav/pet/pet_crd pres_dcu_nus_a.htm

EIA (2015a) Annual Coal Report 2013. Energy Information Administration, Washington, DC

EIA (2015b) Europe Brent Spot Price FOB. US Department of Energy. Energy Information Administration, Washington, DC, Retrieved from http://tonto.eia.gov/dnav/pet/hist/LeafHandler.ashx? $\mathrm{n}=$ PET\&s $=$ RBRTE \& $\mathrm{f}=\mathrm{M}$
EIA (2015) FAQ: How much carbon dioxide is produced when different fuels are burned? Retrieved from http://www.eia.gov/tools/faqs/faq. $\mathrm{cfm} ? \mathrm{id}=73 \& \mathrm{t}=11$

EIA (2016) FAQ: What is U.S. electricity generation by energy source? Retrieved from https://www.eia.gov/tools/faqs/faq.cfm?id=427\&t= 3

Environment \& Energy Publishing (2016) E\&E's POWER PLAN HUB. Retrieved from http://www.eenews.net/interactive/clean power plan

EPA (2015) Clean Power Plan. 80 Federal Register 64661

EPA (2016) Overview of Greenhouse Gases. Retrieved from http:// www3.epa.gov/climatechange/ghgemissions/gases/co2.html

Federal Reserve (2015) Gross Domestic Product: Implicit Price Deflator, Index 2009=100, Quarterly, Seasonally Adjusted. US Federal Reserve Bank, St. Louis, MO, Retrieved from Link: https:// research.stlouisfed.org/fred2

Fullerton, J (2011) The Big Choice. The Capital Institute, Greenwich, CT, Retrieved from capitalinstitute.org/blog/big-choice-0/

Fulton M, Spedding P, Grant A, Leaton J, Capalino R, Sussams L, Gagliardi M (2015) The \$2 trillion stranded assets danger zone. Carbon Tracker Initiative, London, UK

G-7 (2015) Leaders' Declaration. Schloss Elmau, Germany, Retrieved from http://www.consilium.europa.eu/en/meetings/internationalsummit/2015/06/7-8/

Hall B (2005) Innovation and diffusion. In: Fagerberg J, Mowery D, Nelson R (eds) The Oxford Handbook of Innovation. Oxford University Press, New York, NY, pp 459-484

Hayes C (2014) The New Abolitionsim. The Nation

Heede R, Oreskes N (2016) Potential emissions of CO2 and methane from proved reserves of fossil fuels: an alternative analysis. Glob Environ Chang 36:12-20

Hirth L, Uekerdt F (2013) Redistribution effects of energy and climate policy: the electricity markets. Energy Policy 62:934-947

Howard P, Sylvan D (2015) Expert consensus on the economics of climate change. Institute for Policy Integrity, New York University School of Law, New York, NY

IEA (2013) Resources to Reserves. International Energy Agency, Paris, France

IEA (2015a) World Energy Outlook Special Report: Energy and Climate Change. International Energy Agency, Paris, France

IEA (2015b) World Energy Outlook. International Energy Agency, Paris, France

IPCC (2014) Climate Change 2014: Synthesis Report. Intergovernmental Panel on Climate Change, Geneva, Switzerland

Kamien M, Schwartz N (1982) Market structure and innovation. Cambridge University Press, Cambridge, Enlgand

Leaton J, Ranger N, Ward B, Sussams L, Brown M (2013) Unburnable Carbon 2013: wasted capital and stranded assets. Carbon Tracker Initiative \& Grantham Research Institute on Climate Change and the Environment, London, UK

Lewis M (2014) Stranded assets, fossilised revenue. Kepler Cheuvreaux, Paris, France

Linquiti P (2015) The Public Sector R\&D Enterprise. Palgrave MacMillan, New York, NY

Mansfield E (1961) Technical change and the rate of imitation. Econometrica 29(4):741-766

McGlade C, Ekins P (2015) The geographical distribution of fossil fuels unused when limiting global warming to $2^{\circ}$. Nature 517:187-190

McKibben B (2012) Global Warming's Terrifying New Math. Rolling Stone

Meckling J, Kelsey N, Biber E, Zysman (2015) Winning coalitions for climate policy. Science 349(6253):1170-1171

Meinshausen M, Meinshausen N, Hare W, Raper S, Frieler K, Knutti R, Allen M (2009) Greenhouse-gas emission targets for limiting global warming to $2^{\circ} \mathrm{C}$. Nature 458:1158-1162 
Mokyr J (1992) Technological inertia in economic history. J Econ Hist 52(4):325-338

Nelson D, Herve-Mignucci M, Goggins A, Szambelan S, Vladeck T, Zuckerman J (2014) Moving to a low-carbon economy: the impact of policy pathways on fossil fuel asset values. Climate Policy Initiative, London, UK

Pindyck R (2013) Climate change policy: what do the models tell us? J Econ Lit 51(3):860-872

Raupach M, Davis S, Peters G, Andrew R, Canadell J, Ciais P, Le Quere C (2014) Sharing a quota on cumulative carbon emissions. Nat Clim Chang 4:873-839

Reinganum J (1989) The Timing of Innovation: Research, Development, and Diffusion. In: Schmalensee R, Willig R (ed) Handbook of Industrial Organization, Volume 1. Elsevier Science Publishers, Amsterdam, p 850-908

Rogers (1995) Diffusion of innovations, 4th edn. Free Press, New York, $\mathrm{NY}$

Rogner H-H (2012) Energy resources and potentials. In: GEA (ed) Global Energy Assessment. Cambridge University Press, Cambridge, UK and New York, NY, pp 425-467

Rosenberg N (1972) Factors affecting the diffusion of technology. Explor Econ Hist 10(1):3-33
Sapolsky H, Taylor M (2011) Politics and the science of science policy. In: Husbands Fealing K, Lane J, Marburger J, Shipp S (eds) The science of science policy: a handbook. Stanford University Press, Stanford, CA, pp 31-55

Schumpeter J (1943) Capitalism, socialism, and democracy. G. Allen \& Unwin, London

Sinclair U (1935) I, candidate for governor: and how i got licked. University of California Press, Oakland, CA, reprinted December 16, 1994

Tassey G (1997) The Economics of R\&D Policy. Quorum Books, Westport, CT

The Economist (2013) Energy: Blown Away

U.S. Office of Management and Budget (2003) Circular A-4: Regulatory Analysis

Wagner G, Weitzman M (2015) Climate shock: the economic consequences of a hotter planet. Princeton University Press, Princeton, NJ

Weissmann J (2014) Oil Fell Below \$60 a Barrel Today. MoneyBox: A Blog about Business and Economics

Whitney G, Behrens CE, Glover C (2009) U.S. fossil fuel resources: terminology, reporting, and summary. Congressional Research Service, Washington

World Bank (2015) World Development Indicators. World Bank Group, Washington 